\title{
Implementation of Scout Extracurricular Activities at SMPN 10 Surabaya During the Covid-19 Pandemic
}

\author{
Dhiyaul Auliyah ${ }^{1 *}$, Agus Machfud Fauzi ${ }^{2}$
}

\author{
${ }^{1}$ Universitas Negeri Surabaya \\ ${ }^{2}$ Universitas Negeri Surabaya \\ *Corresponding Author. Email:dhiyaul.19001@mhs.unesa.ac.id
}

\begin{abstract}
This study discusses scout extracurricular activities that are still ongoing during the Covid-19 pandemic, departing from the implementation of scout extracurricular activities at State Junior High School 10 Surabaya. Scout extracurriculars are identical with the implementation of outdoor activities, while policies during the learning pandemic are carried out remotely online with the health aspect as the main consideration. The purpose of this study was to determine the implementation of scout extracurricular activities at 10 Surabaya State Junior High School during the Covid-19 Pandemic, as well as the experiences felt by students. The research was conducted using a qualitative descriptive approach with a case study method. The data findings will be analyzed using the Phenomenological Theory proposed by Alfred Schutz. The results showed that the scout extracurricular activities of State Junior High School 10 Surabaya were still being carried out during the Covid-19 pandemic. Scout extracurricular activities are held online according to distance learning policy procedures in Indonesia, with a variety of creative learning strategy policies. In the implementation of online scouting, there are several obstacles. However, with students' creativity and good strategies from the coaches, activities can continue to run well. Students also feel happy every time they take part in a series of activities even from their respective homes, this is because the activities are carried out in a relaxed manner interspersed with joking with many other students.
\end{abstract}

Keywords: Covid-19 Pandemic, Extracurricular, Scouts.

\section{INTRODUCTION}

Education is closely related to pedagogy, which means the science of education. Pedagogy itself is an absorption word from the Greek pedagogues, in Latin it is called pedagogus, which means someone who is in charge of taking children to school and keeping children from behaving according to rules and discipline. Education can also be interpreted from the word educare, which means to lead out. Educare also has a meaning as an effort for the breeding or formation of humans. In accordance with the general agreement, education is a process of transferring human values in the context of the formation of a moral human being. Sociologically, education is a process of forming members in society who have a social spirit, can be useful for other people, the nation, and the state (Soegeng, 2016). The education process itself can run because of rules or enforcement, which are often termed policies.

Policy is often found in the context of government and political context. According to the KBBI, policy is a series of concepts and principles that become the outline and plans in the implementation of a job, leadership, or activity within the organization. Duke and Canady formulated eight directions of policy meaning, (1) policy as an affirmation of goals and objectives, (2) policy is an institution's decision to regulate, control, promote, serve, and so on that has influence within the scope of the agency's authority, (3 ) policy as a guideline for discretionary action, (4) policy as a problem-solving strategy, (5) policy as the imposition of sanctions, (6) policy as a consistent and regular norm of behavior, (7) policy as a result of the policy-making system, (8) policy is the influence generated by policy makers, aimed at public understanding of system implementation (Mu'minah, 2017).

In Indonesia, policies are enforced in almost all areas of life, including education. The Covid-19 pandemic that has hit Indonesia since 2020 has also affected education policy. In the Ministerial Decree 4 concerning Learning Guidelines on April 8,2021 , there are several things that are taken into consideration in policy renewal decisions, including (1) considering the health and safety of all members of the education unit as a top priority during the Covid-19 pandemic, (2) learning needs face-to-face for students who experience distance learning difficulties, (3) efforts to prioritize the health and safety of members of the education unit are carried out with vaccination interventions to speed up face-to-face implementation as well as the implementation of strict health protocols. For sports and extracurricular activities themselves, during the transition period it is not allowed to be carried out in the education unit and it is recommended to keep physical 
activity at home, while later when entering the new habit period it is allowed in the permanent education unit with the application of health protocols (Kemdikbud RI, 2020).

Extracurricular activities are a series of activities designed to develop certain aspects that are interrelated with the curriculum being implemented. Extracurricular also concerns the application of knowledge in the classroom according to the needs and also the surrounding community. This activity is held outside of class hours, with the aim of helping students to be able to develop their talents, interests, as well as their potential. The organizers of this activity are usually carried out by students together with capable and authorized educators in the education unit concerned (Yanti et al., 2016). Extracurricular consists of various activities, including scouting activities. Scouting or scouting activities are a process of learning activities outside the school environment and outside the family environment, which are progressive for young people to develop mentally, morally, spiritually, emotionally, physically, intellectually, and socially as individuals as well as members of society. Usually scouting is synonymous with the implementation of outdoor activities. The purpose of scouting activities is to give birth to a young generation of believers, noble personality, intelligent and strong, and the spirit of Pancasila (Affandi, 2016).

In this study, the focus of the problem is how to carry out scout extracurricular activities at SMPN 10 Surabaya during the Covid-19 Pandemic, as well as the experiences felt by the students. This scouting activity is a means of character education, in order to give birth and strengthen the character of responsibility of students or students as also applied at SMPN 2 Windusari Magelang (Woro \& Marzuki, 2016). At SMAN 1 Sambit Ponorogo, scout extracurricular activities are still carried out online during the pandemic, with several training programs also being carried out online (Ariani, 2021). Another school, SMAN 2 Kerinci, also continues to carry out scouting activities during the pandemic with good activities (Oktapratama, 2021). SDN 1 Pulau Beringin Muaradua Oku Selatan continues to carry out extracurricular activities during the pandemic, the provision of materials and directions is carried out online while physical practice is carried out at their respective homes because they are still vulnerable outside the home (Sari, 2021). This is different from SDN Rembul 2 in Tegal which chose to eliminate the scout movement during the pandemic with consideration of the health priorities of students and other school residents (Asrivi, 2020).

Based on the summary of previous studies, this research certainly has specificity. Previous research is more about generalizing related to whether or not scout extracurricular activities are carried out during the pandemic. In this research, the researcher will explain the implementation of the scout extracurricular activities itself. In addition, researchers will also describe the experiences of students in participating in scout extracurricular activities during this pandemic. The data obtained will then be analyzed by researchers using the phenomenological theory of Alfred Schutz. The purpose of this study was to find out related to the implementation of scout extracurriculars at SMPN 10 Surabaya during the Covid-
19 Pandemic, and also the experiences felt by students in participating in these activities. The researcher hopes that this research can provide both theoretical and practical benefits. The theoretical benefit is that this research is expected to provide a renewal of scientific studies and sociological theories, as well as to be a contribution to courses, especially education policy studies. The practical benefits are expected to be able to add new knowledge as well as develop the writing skills of researchers, as well as as study and evaluation material for practitioners in the world of education.

\section{METHODS}

The approach chosen by the researcher in this study is a qualitative descriptive approach. This approach departs from the phenomena that occur in the field. The data collected as a result of further research will be processed by the researcher to then be able to provide exposure related to the existing data. This is because the nature or design of qualitative research is the researcher self. Researchers conducted research on the implementation of scout extracurricular activities at SMPN 10 Surabaya during the Covid-19 pandemic, to find out the implementation of these activities as well as the experiences felt by students in participating in a series of activities. The research method chosen is case study. Case study as a research method to see the real phenomena that are around. This study will attempt to examine the contemporary phenomenon of the implementation of scout extracurricular activities during the pandemic, especially the scouting unit of SMPN 10 Surabaya. Data collection techniques in this study are primary and secondary data collection. Primary data were obtained from observations and interviews with scout coaches and five student scout members at SMPN 10 Surabaya. Observations will be carried out within a certain period of time as well as interviews are also conducted online according to the current conditions which are still in the Covid-19 pandemic situation. Researchers will also collect secondary data obtained from the results of literature studies, be it books, journals, scientific articles, and so on. The data analysis technique is the researcher's effort to raise the findings at the logical level. Qualitative analysis itself uses an inductive approach where conclusions are drawn from data in the field which lead to general things. In this study, the researcher will analyze the overall data obtained and at the same time explain the relevance of the data findings to the phenomenological theory to understand the experiences felt by students.

\section{RESULTS AND DISCUSSION}

Observations were carried out within a period of one month, namely from August to September 2021. In this case, the researchers focused on a series of scouting activities organized by SMPN 10 Surabaya. The scouting activities of SMPN 10 Surabaya are still ongoing during the Covid-19 pandemic, with the entire implementation online. The first activity is the formation of teams, the students are given instructions to form their respective teams with eight children in one team. The formation of this team was carried out by students online through a chat application on a smartphone. 
After the students got their respective teams they formed a chat group, followed by a discussion of making yells. The chants were made by each student in a short video format, then the video was sent to the chat group to be combined into a series of yelling videos with short videos from other team members.

In the second activity in a different week, the students were asked to take a picture of a coconut shoot, which is a scouting symbol. Students draw coconut shoots first on drawing paper and then color them. The finished image is then cut out following the pattern of coconut shoots. The results of the cutouts are then pasted on cardboard measuring $20 \mathrm{~cm} \times 20 \mathrm{~cm}$. For the collection, students were asked to take a photo of themselves holding the resulting image. In the following week, students were asked to make a line-up practice video. First, the students watched the line-up instruction video sent by the coach through the scouting group chat. Furthermore, students can practice the lines according to the instructions and documented in the form of videos. The video is then sent to the team leader and coach via chat.

Not only that but they were also given assignments to practice scout greetings. The coach first sends instructions and practice video examples. Furthermore, students can practice scout greetings as well as documented in a video. As before, this video is collected by the team leader and coach via chat. Rope activities are also carried out in practice. Students are asked to make anchor knots and base knots which are then asked to collect in the form of photos. In making these anchor and base knots, students are asked to practice with ropes and scout stacks. But not all students have it, as a result, their scout coach proposes an alternative to using things at home. If you don't have a scout rope, students can use raffia or shoelaces instead. Meanwhile, if you don't have a stout stick, you can replace it with a broomstick or a mop stick. The tasks related to passwords in Scouting are also taught and practiced. Students write the scout code work in notebooks, then the results of the work are collected in the form of photos of the team leader and coach. In participating in a series of scouting activities, even though online, students are asked to continue to wear scout uniforms with complete attributes.

In this study, apart from making observations, the researchers also conducted interviews with the scout coaches and five students of SMPN 10 Surabaya. The scout coach of SMPN 10 Surabaya has served there for three years, while he has been a scout coach for 21 years. According to him, the scout extracurricular must still be carried out even in the conditions of the Covid-19 pandemic. Because scouts have always been mandatory extracurricular activities, both at the elementary, junior high, and high school levels. Scouting activities can be carried out indoors or outdoors, for example, bonfires. Logically, it is impossible to make a bonfire indoors, but as creative scout activists, a bonfire is not just wood that is burned with fire, but a symbol of the blaze of spirit. Relying on the creative idea of a bonfire can be done indoors with other media that resembles it as a symbol of a burning spirit, such as using a fan with long red paper attached to make it look like a bonfire.
The activity of setting up a tent can also be done indoors, using alternative tools and materials such as sticks and cloth. So far, the activity of building a tent is identical to an outdoor camp or school area. However, the camp can be conducted online from their respective homes, SMPN 10 Surabaya has held three online camps. The series of activities remain the same as in general camps, including cooking, exploring around the house, as well as morning exercises. Likewise, with other scout activities and equipment, creative scouts can always come up with ideas as an alternative. No scout ropes can be replaced with raffia, no scout sticks can be replaced with broomsticks, no semaphore can be replaced with ordinary wood with red and yellow colored paper attached. The existence of this alternative supports the continuity of activities.

The implementation of scouting activities at SMPN 10 Surabaya is fully online, students are also given material exposure using a meeting platform. The formation of teams and the making of chants were also carried out online through group chats, as well as other activities. The coach considers that this online scout makes students understand the material given by practicing it faster. Operational activities are indeed more dominated by practice when compared to the material. The material is given as a provision and description only, the real application is only in practice. When viewed from the maximum of activities, it can be judged that scouting activities are still not fully maximized. This is due to several inhibiting factors during the implementation of activities.

Inhibiting factors in scouting activities include students who do not have personal cellphones and must use their parents' cellphones. In addition to cell phones, signal problems also hinder the delivery of material. Often suddenly interrupted during the presentation of the material, students sometimes do not understand, but cannot ask freely the supervisor as if the activity was offline. Another factor is that students are sometimes lazy to do the instructions given by the coach. So far the coaches have always tried to overcome these obstacles. As an alternative to the scouting equipment, the coaches also make video tutorials that are uploaded on one of the video streaming platforms so that students can see the activity instructions at any time. To overcome the problem of students' laziness, the coach makes a strategy of practical activities that are carried out more than the material. During practice, the coach asks students to wear full scout uniforms and attributes. In carrying out activities at school, students often only use the uniform of their superiors, because it is like during an online scouting ceremony, students are asked to continue to carry it out standing up. This indirectly makes students move to wear the full scout uniform.

In addition to the existence of inhibiting factors, there are supporting factors in the ongoing online scouting activities. These supporting factors come from all parties, both the school that approves the implementation of the activity, the coach as the supervisor of the activity and the student as the executor of the scouting activity. The implementation of this scouting implementation system is the result of discussions from the coaches and the school. The teaching strategy policy 
is first designed by the coach which is then conveyed to the front group coach. If the design is approved, the front group builder submits it to the vice-principal for student affairs or curriculum. The vice-principal for student affairs then forwards it to the principal, if the principal agrees then the activities can be carried out immediately. In carrying out the activities, the coaches are also assisted by the fundraising council, in which the fundraising council is selected students whose task is to assist the coaches in providing material or practical activities.

Researchers also conducted interviews with five students of SMPN 10 Surabaya who participated in scouting activities. Student A said that he actively participated in scouting activities even though it was carried out online. He also said that he was given tasks including video marches, scout greetings, rigging, and making team chants. Student A admits that he understands the material and assignments given, as well as enjoys participating in scouts even though they are online. In addition to receiving material, he can also easily discuss with his teammates through group chats. The coaches and brothers and sisters in the fundraising council were very helpful during the scouting activities. However, student A often has problems with the signal, so that when an online meeting is sometimes disconnected suddenly.

Student B is also active in every scouting activity that takes place. He said that the series of activities included meetings with coaches and friends, making marching videos, scout greeting videos, and rigging practices. He said he could understand the material and assignments given and could discuss with friends easily. According to him, the scouting activities carried out were fun, he could learn to practice discipline, independence, and be responsible for himself. During the scouting activities, the members of the fundraising council always help. Student B admitted that he had no problems while participating in online scouting activities.

Student $\mathrm{C}$ is active every time the online scouting activity takes place. The series of scouting activities include making teams, making team chants, marching, and rigging. He also understands well the material and assignments given. However, student $\mathrm{C}$ has difficulty discussing with friends because it is not directly, but only through group chats. The online scouting activities were fun, according to student $\mathrm{C}$, the activities were carried out in a relaxed manner, and did not have to think hard. The members of the fundraising board also helped patiently, so that the students could do the assignments properly. The obstacle that is often experienced by student $\mathrm{C}$ is that sometimes it is not clear what is conveyed during a meeting, because the explanation seems short.

Student D is also active in every online scouting activity. The last scouting activity carried out was rigging, students saw the video for example first and then practiced it themselves. He also understands the material and assignments given. According to him, it is easy to be able to discuss later with friends because teams have been formed from the start. The scouting activity that took place according to student D was fun because apart from the material it was also interspersed with jokes so that students did not get bored easily. The brothers from the fundraising council also helped during the activity. During the online scouting, student D admitted that he did not experience any problems.

Student E admitted that he was active in every scouting activity. The tasks given include rigging, marching, and so on. He claimed to be able to understand the material and assignments given well. To discuss with friends is quite easy, it's just that sometimes you also experience signal problems. According to student E, online scouting activities are fun, besides learning, they can also be entertaining because they are together with other friends. During the activity, the students were also assisted by the members of the fundraising council. When participating in his scouting activities, student $\mathrm{E}$ did not experience any problems.

\subsection{DISCUSSION}

Based on the results of the study, it can be seen that the scouting activities of SMPN 10 Surabaya continued during the Covid-19 pandemic. The coach decided this because this extracurricular has always been mandatory at the elementary, junior high, and high school levels. This Scout extracurricular as a compulsory education curriculum becomes a pillar of character education (Lassura, 2021). The coaches of SMPN 10 seem to have a mature strategy in implementing scouting during the Covid-19 pandemic. Policy-making to continue carrying out scouting activities is also by the policy of the Indonesian Ministry of Education and Culture regarding Distance Learning (PJJ) during the Covid-19 pandemic, to prevent wider transmission, especially the scope of education (Basar, 2021). The Scouts of SMPN 10 Surabaya as a whole are online, with the implementation of various teaching strategies that have been decided by the coach and the school.

For the coaches of SMPN 10 Surabaya, scouts are an extracurricular full of creativity from the implementers. We can see this together through a demonstration of the imitation of a bonfire as a symbol of a burning spirit, namely by using a fan that is given a long piece of red paper so that it resembles a fire. Previously, of course, this had never been thought of, the important point is that students must be able to interpret and build their passion as a young generation. Some other values of the bonfire are strengthening brotherhood, creating a free and happy atmosphere, developing creativity, and so on (Maharani, 2021). The series of activities carried out are still like scout activities in general. In the beginning, all students were asked to form teams with eight students in each team. In this case, the coach only gives instructions, which then the students will start forming their respective teams online through the chat application.

After forming a team, students are also asked to make their team chants. This will indirectly create cohesiveness among students. The Covid-19 pandemic has an impact because of the real scope of scouts in nature and the community, but this does not dampen the enthusiasm to continue scout activities even though they are online (Mustika \& Mulyadi, 2021). Not only forming teams and making chants but other activities were also carried out such as drawing coconut shoots, practicing marching activities, practicing scout greetings, 
practicing rigging by making anchor knots and base knots, as well as writing grass codes. All activities are collected in the form of documentation in the form of photos and videos. Furthermore, the photos or videos are collected by the head of each team and also by the scout coach.

In the practice of rigging, students need a stick and a scout rope. But not all students have it, from this problem students' creativity also develops. As with imitation media for bonfires, the coach gives insight to students to use broomsticks or mop sticks at home as an alternative to scout stacks. If you don't have a scout rope, students can also use raffia or shoelaces that you have at home. Likewise in making tents, broomsticks and cloth can be used to make tents in the house. Another scout equipment is semaphore which can also be tricked by using wood attached with red and yellow paper. All of the alternatives chosen besides being able to increase students' creativity, can also be of economic value because students do not have to spend money to buy new equipment. Especially during the current Covid-19 pandemic which has an impact on economic sluggishness due to a decrease in population income (Putra \& Kasmiarno, 2020). Students can use a variety of alternative objects at home.

The implementation of scouting activities at SMPN 10 Surabaya is more practical than providing material. This is because the coach assesses the implementation of online scouts students are better able to understand the application of the material by practicing directly and independently. Even so, the material is still provided as an illustration and insight for students. The provision of material is usually done through group chats or platform meetings. Efforts to make every scouting activity a success have been carried out by all parties. But if it is related to its maximums, online scouting activities are not as optimal as when carried out offline or offline. This is because there are still several inhibiting factors in the running of the activity.

The inhibiting factors include students who do not have their cellphones and use their parents' cellphones. For those whose parents both work, the task must be delayed until the evening because they are waiting for their parents' cell phones to work on them. During the meeting session, signal problems sometimes also make the explanation of the material suddenly cut off so that students cannot understand the overall material. The feeling of laziness that some students have is also classified as an obstacle to the implementation of scouting. However, the supervisor of SMPN 10 Surabaya has a strategy in minimizing the existing inhibiting factors. For those who have to postpone assignments because they don't have personal cellphones, the coaches outsmart them with material or task instructions in the form of videos uploaded on one of the video streaming platforms so that students can access them all the time. It is also classified as more efficient, students can watch videos and study them repeatedly if something is not understood. In addition, the coach always asks students to wear uniforms and complete attributes, it indirectly inspires students' willingness and enthusiasm to participate in scout extracurricular activities.
Among the existence of inhibiting factors, there are also supporting factors, one of which is from the school. This support is evidenced by the agreement in the draft teaching strategy policy that has been proposed by the coach. Operationally, based on the results of interviews, the process of submitting a teaching strategy design coherently starts from the smallest structure to the highest structure. The coach submits the scout extracurricular teaching plan first to the front group coach. If approved, this design is informed to the vice-principal for student affairs or curriculum. Furthermore, the vicechairman of the curriculum informs the head of the school as the highest structure. If approved, the teaching strategy can be applied immediately. The online scout extracurricular activities have been prepared in such a way by the coaches so that they can be approved and implemented. The coaches are also assisted by a fundraising board consisting of selected students to assist the coaches during extracurricular activities.

Based on the results of interviews with five students of SMPN 10 Surabaya, it can be seen that students from students $\mathrm{A}, \mathrm{B}, \mathrm{C}, \mathrm{D}$, and $\mathrm{E}$ are always actively participating in the implementation of scout extracurricular activities. They can also tell about some of the material or tasks given during scouting such as forming teams, making yells, scout greetings, rigging, and marching. The practice of marching and other practices can develop the discipline character and concentration of students (Ulfah, 2017). In practice, the five students said they could understand the material as well as the given task well even though it was done online. For the ease of discussing with friends, students A, B, and D find it easy to discuss because, from the start, teams have been formed and have their chat groups. In contrast to student $\mathrm{C}$ who finds it difficult because they do not discuss directly or offline, also student D often experiences signal problems.

The five students also said that they enjoyed participating in a series of scouting activities in various expressions. Student A said the scouting activities were fun even though it was done online. Student B stated that scouting activities were fun as well as beneficial to train discipline, independence, and also a sense of responsibility towards themselves. This shows that scouts play a role in the implementation of character education, especially in fostering student discipline in participating in teaching and learning activities (Nurhidayat, 2018). Students $\mathrm{C}, \mathrm{D}$, and $\mathrm{E}$ have the same answers. They revealed that scouting activities were carried out in a relaxed manner interspersed with jokes. Activities carried out simultaneously with all students of course as well as entertainment for students, and make students not feel bored throughout the series of activities.

When participating in scouting activities, the five students unitedly said that the coaches and the members of the fundraising council always helped them patiently. This is so that when students understand the material and assignments, they can do it correctly. In carrying out online scout extracurricular activities, it seems that there are also obstacles experienced by students. Student A said that he often had problems with the signal, which caused the meeting 
connection to suddenly be disconnected. Meanwhile, student C experienced problems, namely the material presented during the meeting seemed short so that it was sometimes unclear when understanding. Meanwhile, students B, D, and E admitted that they did not experience any problems while participating in online scouting activities.

The existing phenomena are relevant to the phenomenological theory of Alfred Schutz. Schutz stated that human action becomes a social relationship if the human being gives meaning to his actions. Furthermore, this action is understood by other humans as something meaningful. This understanding is subjective and decisive in the continuation of the process of interaction between humans because after interpreting, humans will react and be responded to by other humans. This subjectivity refers to general awareness to group awareness to integrate. A group of individuals who have group awareness will give birth to social interaction, this is determined by the knowledge and experience of each individual. The four main elements in this theory are (1) the attitude of attention from other individuals towards the actor,

(2) focusing on important facts with a natural and natural attitude, (3) focusing attention on micro problems, and (4) paying attention to growth, change, and action processes are created and maintained (Ritzer, 2014).

Judging from the experiences expressed by the five students above that they are active in scouting activities can also understand the material and assignments given. This shows that students A, B, C, D, and E give focus their attention on the trainer or board member presenting material or task instructions. Before holding the meeting, of course, the coaches and the fundraising board gave instructions through the chat group so that all students saw and participated in the activities on that day. This is a reality that students face, then respond naturally and naturally to follow. At SMPN 10 Surabaya, scout extracurricular activities are mandatory extracurricular activities. In students making themselves focus on following the scouts, this indirectly raises a group awareness in students. If each student already has group awareness to integrate, then the process of implementing online scouting activities is formed as a social association. Students are provided with the knowledge and experience that scouts are a mandatory extracurricular activity that must be followed in addition to daily teaching and learning activities.

The focus on micro-problems in this phenomenon is scouting activities carried out online. Various problems arise in the implementation of online scouting, ranging from ownership of scout equipment and accessories, ownership of mobile phone facilities as online access, signal network problems when online scouting is in progress, as well as student laziness which can hinder the smooth running of activities. The actors starting from the students and also the coaches focus their attention on the internal micro problems of the group. The coaches also make strategies to minimize the problems experienced by students, especially in participating in online scouts. For the ownership of equipment and accessories, the coaches outsmart them so that students can use things or objects that are at home as an alternative. Such as scout ropes are replaced with raffia or shoelaces, also scout sticks are replaced with broomsticks or mop handles.

For problems related to ownership of cellphone facilities as online access, not all students have their cellphones, some students have to use their parents' cellphones after their parents come home from work. Mobile phones are the most effective learning media to be used in distance learning as it is today (Maknuni, 2020). The coach uses a strategy of providing material and assignment instructions in a video format that is uploaded to a video streaming platform so that students can access it all the time. This is also anticipation for students if there is material or assignments that have not been understood, they can do their understanding again by watching the video. In addition, if there is a signal problem, students can access the video when their signal is in good condition. Feelings of laziness also often hit students, but the coach's strategy so that students want to move from wearing uniforms and complete attributes each scout takes place helps minimize this.

Three points in the four main elements of phenomenological theory can be seen from the description above. The fourth point related to growth, change, and the process of creating and maintaining action is seen in the formation of online scout learning strategy policies. The changing times since the emergence of Covid-19 as a pandemic have also changed several things in education. As in the implementation of scouts at SMPN 10 Surabaya during the Covid-19 pandemic, it was carried out online. The existence of the Covid-19 pandemic can be said to be the beginning of the transformation of the digitalization of education. The teaching method is adjusted to the needs of each component of the educational institution (Maksum \& Fitria, 2021). Policies related to the implementation of scouting activities as the creation of the action process begins. The coach first submits the draft teaching strategy to the front group coach, followed by the vice principal for student affairs until it is approved by the principal. After the idea is approved, the implementation of online scouts follows the rules and is automatically maintained in every activity that takes place. From this it can be seen that from all the actions taken by the scouts, both coaches and students, there are meanings, actions and reactions that appear to establish a social association. Integration is getting stronger because within each individual involved there is already a group consciousness.

\section{CONCLUSION}

The conclusion from the overall explanation above is that the scout extracurricular activities of SMPN 10 Surabaya are carried out online. This implementation policy has been carefully designed by the supervisor and approved by the principal. Scout activities continue to be carried out as a series of scouts when offline, including forming teams, making yells, marching practices, rigging practices, drawing scout symbols, and scout codes. All students of SMPN 10 Surabaya actively participate in scouting activities, they can also understand the material and their assignments. Students feel happy when doing activities, although there are still several factors that become obstacles in online scouting. However, these obstacles 
can be minimized by various coaching strategies such as making video materials and task instructions in video formats uploaded on streaming platforms, using alternative objects as scout equipment, and so on. The actions taken by the coaches and students provide a meaning so that group awareness arises for the optimal implementation of online scouts. The feeling of laziness that still exists among some students can certainly be minimized by group awareness of other students. It would be better if the coaches inform all students of this so that students who are always active can give meaning to group awareness to those who are still lazy so that all students can contribute to online scout extracurriculars.

\section{ACKNOWLEDGMENTS}

The researcher would like to thank the supervisors who have been willing to help and guide during the research. The researcher also thanked the conference committee for allowing researchers to contribute. And the researcher would like to thank his family and friends who always give their support.

\section{REFERENCES}

[1] Affandi, M. R. (2016). Pelaksanaan Kegiatan Ekstrakurikuler Pramuka Dalam Pembentukan Karakter Siswa Di Mi Tasmirit Tarbiyah Trenggalek. Laporan Tesis, 01(01), 1-139.

[2] Ariani, R. (2021). Manajemen Kesiswaan dalam Pengembangan Bakat Siswa melalui Program Ekstrakurikuler di SMA Negeri 1 Sambit Ponorogo. http://etheses.iainponorogo.ac.id/id/eprint/15141.

[3] Asrivi, Q. E. S. (2020). Implementasi Pramuka Sebagai Ekstrakulikuler Wajib Kurikulum 2013 Sekolah Dasar. Jurnal Pendidikan Dasar: Jurnal Tunas Nusantara, 2(2), $255-268$.

https://ejournal.unisnu.ac.id/jtn/article/view/1483.

[4] Basar, A. M. (2021). Problematika Pembelajaran Jarak Jauh Pada Masa Pandemi Covid-19. Edunesia: Jurnal Ilmiah Pendidikan, 2(1), 208-218. https://doi.org/10.51276/edu.v2i1.112.

[5] Kemdikbud RI. (2020). Panduan Pembelajaran Jarak Jauh. Kementrian Pendidikan Dan Kebudayaan, 021, 28. https://bersamahadapikorona.kemdikbud.go.id/panduanpembelajaran-jarak-jauh/.

[6] Lassura, A. (2021). Kendala Dalam Pelaksanaan Kegiatan Pramuka Di Masa Pandemi Covid -19. 2(20), 23-38.

https://media.neliti.com/media/publications/347335kendala-dalam-pelaksanaan-kegiatan-pramu45642795.pdf.

[7] Maharani, S. A. (2021). Makalah Pramuka Api Unggun. https://pdfcoffee.com/qdownload/makalah-pramuka-apiunggun-uas-pdf-free.html.

[8] Maknuni, J. (2020). Pengaruh Media Belajar Smartphone Terhadap Belajar Siswa Di Era Pandemi
Covid-19 (The Influence of Smartphone Learning Media on Student Learning in The Era Pandemi Covid-19). Indonesian Education Administration and Leadership Journal (IDEAL), 02(02), 94-106. https://onlinejournal.unja.ac.id/IDEAL/article/view/10465.

[9] Maksum, A., \& Fitria, H. (2021). Transformasi dan Digitalisasi Pendidikan Dimasa Pandemi. Prosiding Seminar Nasional Pendidikan, 121127. https://jurnal.univpgri-

palembang.ac.id/index.php/Prosidingpps/article/downlo ad/5498/4827.

[10] Mu'minah. (2017). Analisis Implementasi Full Day School Dalam Upaya Membentuk Akhlak Karimah Siswa di SMP IT Permata Bunda Mranggen Demak. 20(2), 140-142.

http://eprints.walisongo.ac.id/7483/2/BAB I.pdf.

[11] Mustika, F. J., \& Mulyadi, D. (2021). Menanamkan Sifat Kebangsaan Pada Generasi Muda Meskipun Di Era Pandemi (Studi Kasus Di Kwartir Cabang Kota Cimahi). 6(1), 42-47.

[12] Nurhidayat, H. (2018). IMPLEMENTASI PENDIDIKAN KARAKTER MELALUI PEMBELAJARAN PRAMUKA UNTUK MENGEMBANGKAN KEDISIPLINAN SISWA DI MIN 4 KABUPATEN MADIUN. http://etheses.iainponorogo.ac.id/3803/1/HERI PDF.pdf.

[13] Oktapratama, R. (2021). AKTIVITAS SISWA SMA NEGERI 2 KERINCI EKSTRAKURIKULER PRAMUKA PADA MASA PANDEMI COVID-19. 7(1), 6. https://repository.unja.ac.id/22573/.

[14] Putra, M. W. P., \& Kasmiarno, K. S. (2020). Pengaruh Covid-19 Terhadap Kehidupan Masyarakat Indonesia: Sektor Pendidikan, Ekonomi Dan Spiritual Keagamaan. POROS ONIM: Jurnal Sosial Keagamaan, 1(2), 144159. https://doi.org/10.53491/porosonim.v1i2.41.

[15] Ritzer, G. (2014). Sosiologi Ilmu Pengetahuan Berparadigma Ganda. PT RajaGrafindo Persada.

[16] Sari, S. I. (2021). IMPLEMENTASI EKSTRAKURIKULER DI MASA PANDEMI DI SD NEGERI 1 PULAU BERINGIN MUARADUA OKU SELATAN. http://repository.radenfatah.ac.id/9481/.

[17] Soegeng, A. Y. (2016). KONSEP PENDIDIKAN DAN PENGAJARAN RANGKUMAN TELAAH KRITIS PERBEDAAN, HUBUNGAN,

DAN PENERAPANNYA. Prosiding Upgris, 1-13. http://prosiding.upgris.ac.id/index.php/fip_2016/fip_201 6/paper/viewFile/1594/1549.

[18] Ulfah, I. A. (2017). IDENTIFIKASI KEGIATAN PRAMUKA DALAM MENGEMBANGKAN KARAKTER DISIPLIN SISWA DI SD NEGERI 01 BOLONG KARANGANYAR. https://media.neliti.com/media/publications/347335kendala-dalam-pelaksanaan-kegiatan-pramu45642795.pdf. 
[19] Woro, S., \& Marzuki, M. (2016). Peran Kegiatan Ekstrakurikuler Pramuka Dalam Pembentukan Karakter Tanggung Jawab Peserta Didik Di Smp Negeri 2 Windusari Magelang. Jurnal Pendidikan Karakter, 1, 5973. https://doi.org/10.21831/jpk.v0i1.10733.
[20] Yanti, N., Adawiah, R., \& Matnuh, H. (2016). Pelaksanaan Kegiatan Ekstrakurikuler Dalam Rangka Pengembangan Nilai-Nilai Karakter Siswa Untuk Menjadi Warga Negara Yang Baik Di Sma Korpri Banjarmasin. Jurnal Pendidikan Kewarganegaraan:, 36(10), 1573-1576. 